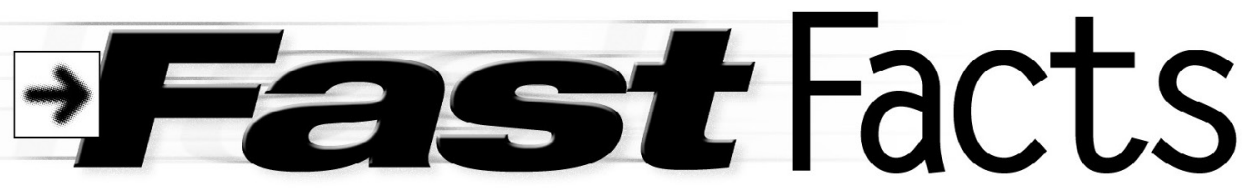

\title{
Fact checking
}

"The number of active fact-checkers around the world has topped 300-about 100 more than the Duke Reporters' Lab counted this time a year ago. Some of that growth is due to the 2020 election in the United States, where the Lab's global database and map now finds 58 fact-checking projects. That's more than twice as many as any other country, and nearly a fifth of the current worldwide total: 304 in 84 countries."

Mark Stencel and Joel Luther, "Fact-Checking Count Tops 300 for the First Time," Duke Reporters' Lab, October 14, 2020, https://reporterslab.org/fact-checking-count-tops-300-for-the-first-time (retrieved May 3, 2021).

\section{Streaming music}

Streaming music revenue reached an all-time high of $\$ 13.4$ billion. This accounts for more than 62 percent of worldwide recorded music sales.

IFPI, "IFPI Issues Global Music Report 2021," March 23, 2021, https://www.ifpi.org/ifpi-issues-annual-global-music-report-2021 (retrieved May 4, 2021).

\section{Remedial postsecondary education}

For fall 2009, ninth-graders whose first postsecondary enrollment after high school was in 2013-14 (latest data available), postsecondary transcript data indicate that 41 percent had taken one or more remedial courses as of June 2016. These students took an average of three remedial courses and passed an average of two of them during this period. Xianglei Chen, Michael A. Duprey, Nichole Smith Ritchie, Lesa R. Caves, Daniel J. Pratt, David H. Wilson, Frederick S. Brown, and Katherine Leu, High School Longitudinal Study of 2009 (HSLS:09) A First Look at the Postsecondary Transcripts and Student Financial Aid Records of Fall 2009 Ninth-Graders (NCES 2020-003), U.S. Department of Education, Washington, D.C. National Center for Education Statistics, https://nces.ed.gov/pubsearch/pubsinfo. asp?.pubid=2020003 (retrieved May 3, 2021).

\section{Undergraduate enrollment}

"Spring undergraduate enrollment was down 5.9 percent compared to the same time last year. Community college enrollment fell by double digits ( -11.3 percent) for the first time in this pandemic. Graduate enrollment, on the other hand, continued to grow this spring (+4.4 percent). Overall postsecondary enrollment was down 4.2 percent from a year ago." National Student Clearinghouse, "COVID-19: Stay Informed with the Latest Enrollment Information," April 29, 2021,. https:// nscresearchcenter.org/stay-informed (retrieved May 4, 2021)

\section{Global Internet users}

The number of Internet users worldwide grew by more than 330 million over the past year, reaching a total of 4.72 billion at the start of April 2021. There are 5.27 billion mobile phone users and 4.33 billion active social media users.

Simon Kemp, "Digital 2021 April Global Statshot Report," DataReportal, April 21, 2021, https://datareportal.com/reports /digital-2021-april-global-statshot (retrieved May 4, 2021).

\section{Stranded college credits}

"Roughly 6.6 million students may have stranded credits-academic credits they earned but cannot access because they have an unpaid balance with a previously attended institution that is holding their transcript as collateral. Adult learners, lower-income students, and racial and ethnic minority students are the most likely to owe outstanding balances to previously attended institutions, and therefore most likely to have stranded credits." Julia Karon, James D. Ward, Catharine B. Hill, and Martin Kurzweil, "Solving Stranded Credits: Assessing the Scope and Effects of Transcript Withholding on Students, States, and Institutions," Ithaka S+R. October 5, 2020, https://doi.org/10.18665 /sr.313978 (retrieved May 4, 2021).

Gary Pattillo is reference librarian at the University of North Carolina-Chapel Hill, e-mail: pattillo@email.unc.edu 